\title{
Environmental Proactivity \\ In Manufacturing Industries: Is It Valuable?
}

Conrado Carrascosa-López, Universitat Politècnica de València, Spain

María-del-Val Segarra-Oña, Universitat Politècnica de València, Spain \& International Network for Economic Research on

Tourism and Environment, INERTE

Angel Peiró-Signes, Universitat Politècnica de València, Spain

Baldomero Segura-García-del-Río, Universitat Politècnica de València, Spain

\begin{abstract}
The purpose of this paper is to study the concept of environmental proactivity and its application to manufacturing industries. The literature on environmental proactivity and its application to different types of industries is reviewed. This paper examines the latest trends in the field and verifies their practical applicability and usefulness for companies. Increasing companies' competitiveness is key to their survival; interestingly, environmental proactivity can improve companies' productivity, and hence their competitiveness. The concept of environmental proactivity is often viewed with suspicion by manufacturing firms; in this work, a positive view of the concept of environmental proactivity is presented. This paper includes case studies of the application of environmental proactivity to three industrial sectors as well as a quantitative study to verify the results. The paper's conclusion is that the adoption of a proactive environmental approach provides benefits to companies in terms of image enhancement, cost savings, and new business opportunities, all of which contribute to the sustainable growth of companies.
\end{abstract}

Keywords: Environmental Proactivity; Sustainability; Productivity; Competitiveness

\section{INTRODUCTION}

nterest in environmental care has increased across many fields in recent years (Vargas-Vargas et al., 2010). Global demand for low-environmental-impact and high-energy-efficiency products is increasing (Porter, Van der Linde, 1995). Throughout history, the industrial sector has been responsible for largescale environmental degradation; however, industry's negative impact on the environment has decreased because of the growth of environmental awareness and the implementation of legislative changes to control industry's environmental impact (Fairchild, 2008).

Environmental proactivity is defined as the voluntary implementation of practices and initiatives aimed at improving companies' environmental performance (Gonzalez-Benito, Gonzalez-Benito, 2006). Determinants of environmental proactivity can be classified as internal or external to the company. Internal factors that can influence a company's environmental proactivity include the size of the company, support and commitment level of management, and whether the company is part of a larger corporation. External factors bearing on environmental proactivity include industrial sector (each sector has different pollution potential and it is controlled by public administrators in different ways) and location (environmental legislation and social pressure depend on where a company is located) (González-Benito, González-Benito, 2006). Stakeholder commitment is considered essential for the development of proactive environmental strategies (González-Benito, González-Benito, 2010). Aragón-Correa et al. (2008) study small and medium enterprises (SMEs) and conclude that large company size aids the adoption of environmentally proactive policies; however, Aragón-Correa et al. also note that small company size does not completely prevent a business from adopting proactive environmental strategies. The relationship between pressure from stakeholders and proactive environmental practices varies by firm size. Small firms are more sensitive to these pressures and are more motivated to improve environmental performance (Darnall et al., 2010). However, not all companies respond well to internal pressure to increase environmental proactivity. Gadenne et al. (2009) note that 
even among companies with managers who have environmentally friendly attitudes, some still have poor environmental practices.

It is necessary to look beneath the surface of companies, considering their fundamental absorptive capacities (Delmas et al., 2011) to identify those that are capable of adopting sustainable strategies successfully. Environmentally positive attitudes are not always linked with decisions that improve environmental performance; this is why empirical studies are recommended (Gadenne et al., 2009).An empirical approach is necessary in order to compare the effects of factors affecting environmental performance and to identify what influences each of them. (González-Benito, González-Benito, 2006, Aragón-Correa, Sharma, 2003).

Several research papers describe benefits obtained by increasing environmental proactivity. For example, Aragón-Correa (1998) defines the positive impact of environmental proactivity in terms of the competitive advantages it affords to companies. There are situations wherein proactive behavior produces benefits for both the environment and companies (King, Lenox, 2001). A current research trend specifies and analyzes each benefit afforded to companies by increased environmental proactivity, such as corporate image improvement (Buysse and Verbeke, 2003). González-Benito's paper (2005) reveals that some aspects of environmental proactivity lead to positive effects in both company performance and marketing. In the research of Gadenne et al. (2009), more benefits conferred to companies by environmental proactivity are listed, including waste reduction, cost savings, increased customer satisfaction, product improvements, and public relations benefits. More recent research adds that environmental proactivity aids internationalization processes (Martín-Tapia et al., 2010) and even leads to improvements in companies 'financial resources (Clarkson et al., 2011).Other researchers explore the link between environmentally friendly management techniques and value creation. For example, a case study verifies that certification under ISO 14001 (the International Organization for Standardization's environmental management standard) leads to company changes that may be transformed into benefits (Rondinelli, Vastag, 2000). Melnyk et al. (2003) demonstrate in a larger study of the US industrial sector that ISO 14001 certification brings real benefits. Darnall et al. (2008) find, in a sample of industrial companies in Canada, Germany, Hungary, and the United States, that implementing environmental management systems confers empirical benefits and creates potential business value for companies. In Spain, Segarra et al. (2011) reveal the same positive relationship in the food industry. Rivas and Magadán (2010) propose a theoretical framework under which the Spanish government could reduce taxes on green companies and increase control over industries that pollute the most.

The most common method of studying corporate environmental proactivity is through quantitative studies based on surveys or interviews (Aragón-Correa, 1998, King, Lenox, 2001; Menlyk, 2003; Buyssey Verbeke, 2003; González-Benito, González-Benito, 2005; Butler, 2008; Darnall et al., 2008; Murillo-Luna et al., 2008; Darnall et al., 2010; Martín-Tápia et al., 2010; Haddock-Fraser, Tourell, 2010;Delmas et al., 2011; Clarkson et al., 2011; Segarra, 2011). Statistical studies confirm correlations among different aspects, but provide no evidence on causality (González-Benito, González-Benito, 2010). Some case studies have been conducted, although the sample sizes for these are smaller than those in statistical studies (Rondinelli, Vastag, 2000; Gadenne et al., 2009). Case studies can provide a better understanding of the true effects of environmental proactivity, and may prove whether it can provide real benefits.

Some authors criticize an excessively positive view of environmental proactivity; to a certain extent, they challenge the hypothesis that "it pays to be green". For instance, King and Lenox (2001) argue that research linking improved environmental performance with improved financial performance often lacks enough longitudinal information to verify this relationship. It is difficult to confirm the value of "being green in a sector" versus "being in a green sector."Therefore, the most important question in this field is, "When does it pay to be green?" The relationship between having a proactive strategy towards the environment and gaining a competitive advantage may not always be positive; it depends on the characteristics of the business environment, such as uncertainty and complexity, among others (Aragón-Correa, Sharma, 2003). It has not always been possible to find evidence that environmental proactivity ensures greater profitability, at least in the short term (González-Benito, González-Benito, 2005). The first step in answering the question, "When does it pay to be green?" is to classify environmental investments according to their potential to yield competitive advantages. Orsato (2006) identifies four types of environmental strategies and indicates which competitive advantages may be obtained from each. 
Some companies facilitate environmentally proactive strategies; however, in some companies, obstacles can stand in the way of adoption (Aragón-Correa, Sharma, 2003).The difficulties faced by companies who want to adopt more proactive environmental policies have not been well studied. Lack of financial resources is one of the major barriers hindering the development of proactive environmental practices (Gadenne et al., 2009).

\section{OBJECTIVES AND METHODOLOGY}

This study's main objective is to perform an in-depth analysis of industry's environmental proactivity in the Valencian Community region of Spain. A rigorous study of industry's internal motivating factors with respect to environmental proactivity requires controlling for external factors, including environmental legislation, industrial sector, and location. Environmental legislation in Spain is not uniform throughout the country; part of the responsibility for environmental legislation lies with the governments of autonomous communities. Therefore, this study takes place solely within the Valencian Community, a geographic area with uniform environmental laws.

This research is divided into two independent but interconnected phases. In the first phase of the study, three empirical case studies are performed, one on each of the three major industrial sectors of the region. In the second phase of the study, a quantitative analysis is performed in order to verify and reinforce the first two hypotheses tested in the case studies. The analysis method used in this study allows comparison and contrast between information obtained from case studies and information obtained via quantitative analysis.

\section{THREE CASE STUDIES: THE MOST IMPORTANT INDUSTRIAL SECTORS OF THE VALENCIAN COMMUNITY}

Case studies were conducted on the three most important sectors in the Valencian Community's economy in terms of export volume: the automotive sector, food industry, and tile industry. In 2010, the automotive sector produced $17 \%$ of the region's total export volume, the food industry produced $14 \%$, and the tile industry produced 9\% (IVEX, 2011).

The three case studies had the same structure. The first objective was to identify facilitators of environmental proactivity; company characteristics that help to develop proactive environmental performance were identified, such as company size, internationalization, and direct involvement of management. The second objective was to identify the obstacles inhibiting a company's adoption of an environmentally proactive approach. The third objective was to identify the benefits a company can expect after the adoption of a proactive environmental policy. Heterogeneous samples of firms were selected after appointments were made with company environmental officers. The company environmental officers were asked to complete verbal surveys that included Likert-scale questions and items designed to bear on each of the three hypotheses. The visits were conducted in person by a researcher, who made observations directly and indirectly. The data were analyzed in order to derive conclusions based on the following three hypotheses:

H1: Large company size facilitates environmental proactivity, and small size is a barrier to it.

H2: International competition facilitates environmental proactivity.

H3: Direct involvement of management is essential to facilitate environmental proactivity.

\section{Automotive sector case study}

A sample of five enterprises in the automotive sector was chosen, of which two were large multinational companies and three were SMEs. One SME was a multinational, and the remaining two conducted their activities only in Spain. Among the sample, all companies were ISO 14001 certified.

All three hypotheses were supported by the results of this case study, because the most proactive companies were multinational, large, and their management teams were highly involved with environmental issues.

The main obstacles to environmental proactivity faced by these companies were a lack of financial and institutional support. The main benefits expected by the companies after becoming more environmentally proactive 
were corporate image improvement, avoidance of punitive economic sanctions, and long-term economic benefits (Segarra et al., 2011).

\section{Food industry case study}

A sample of 18 companies in the food industry was chosen, of which $38 \%$ were large and $62 \%$ were SMEs. Twenty-eight percent of the companies were multinational, and the remaining $72 \%$ conducted their activities only in Spain. Among the sample, 55\% of the companies were ISO 14001 certified.

$\mathrm{H} 2$ and $\mathrm{H} 3$ were supported by the results of this case study. H1 was only partially supported by the results of the case study: it was observed that large firms generally have better environmental performance than SMEs, but one SME had excellent environmental performance; its performance was even better than that of some of the large companies in the sample. This exceptional SME competed internationally and its management was very involved with environmental proactivity. In this sector, management involvement with environmental policy and international competition appeared to be much more decisive than company size in determining companies' environmental proactivity.

The main obstacles to environmental proactivity faced by these companies were a lack of financial resources, institutional support, and access to information on environmental management systems. The main benefits expected by the companies after becoming more environmentally proactive were corporate image improvement, avoidance of punitive economic sanctions, long-term economic benefits, and the creation of new business opportunities (Segarra et al., 2011).

\section{Tile industry case study}

A sample of 14 companies in the tile industry was chosen, of which $30 \%$ were large and $70 \%$ were SMEs. Fifty percent of the companies were multinational, and the remaining fifty percent conducted their activities only in Spain. Among the sample, $71 \%$ of the companies were ISO 14001 certified.

Only $\mathrm{H} 2$ and $\mathrm{H} 3$ were supported by the results of this case study. Some companies in the sample were small, but competed internationally and had management teams that were highly involved with environmental issues. Therefore, is impossible to conclude based on data from the tile industry that small company size is a barrier to environmental proactivity. In this sector, like in the food industry, management involvement and international competition appeared to be much more decisive than company size in determining companies' environmental proactivity.

The main obstacles to environmental proactivity faced by these companies were a lack of financial resources, institutional support, and information on environmental management systems. The main benefits expected by the companies after becoming more environmentally proactive were corporate image improvement, avoidance of punitive economic sanctions, long-term economic benefits, and the creation of new business opportunities.

\section{QUANTITATIVE STUDY}

In the quantitative study, the first and second hypotheses were tested on a broader sample.

H1: Large company size facilitates environmental proactivity, and small size is a barrier to it.

H2: International competition facilitates environmental proactivity.

Information for the quantitative study was obtained from the Technological Innovation Panel (PITEC) database. This database was compiled by the Spanish National Statistics Institute (INE). It includes listings of Spanish firms classified by innovation types, industrial sector, and location; 255 total variables are analyzed in the INE database. The sample analyzed for this study consisted of data collected in 2008 on 268 firms in the automotive industry. Variables analyzed in this study were selected according to the theoretical framework of the hypotheses and included net sales, total goods investment, number of employees, Spanish national market share, European 
market share, total investment in internal and external research and development (R\&D), number of full-time employees who work on R\&D activities, number of national patents, and number of European patents. An exploratory factor analysis was performed on all ten independent variables. The factor analysis yielded four main factors: size, open market orientation, formal innovative activity, and total innovation investment, which accounted for $80.83 \%$ of the variance. Among these four factors, factor size and export orientation had a consistent weight. The model's dependent variable is titled "EFECTO 8" in the PITEC database; it measures the necessity for innovating firms to reduce environmental impact.

Correspondence analysis concluded that companies operating only in Spain tended to show little interest in environmental proactivity, whereas international companies showed medium or high interest rates in environmental proactivity (Segarra el al., 2011).

\section{CONCLUSIONS}

Quantitative analysis demonstrated that large company size is a facilitator for environmental proactivity, verifying statements made by González-Benito and González-Benito (2006) and Vargas-Vargas et al. (2010). The case studies of the tile industry and the food industry showed that small company size was not an insurmountable barrier to environmental proactivity. This confirmed Aragón-Correa et al.'s (2008) findings regarding the environmental proactivity of SMEs. H2 was supported by both the case studies and the quantitative analysis: companies that compete internationally demonstrated more proactive environmental behaviors. These findings validated Martín-Tapia et al.'s (2010) hypothesis that environmental proactivity aids companies in the internationalization process. It also stands to reason that international companies are externally pressured to minimize their impact on the environment much more than companies that do not export their products. Spanish industry lags behind other EU members in terms of its environmental conscience (Vargas-Vargas et al., 2010); therefore, export-oriented businesses are more likely to improve environmental performance. This demonstrates that international competition and environmental conscience are two factors that have a synergistic influence on environmental proactivity. H3was verified in the three case studies performed for this study: motivation and management involvement are necessary for the adoption of environmentally proactive policies, as stated by Villavicencio (2007).

In the automotive sector case study, all firms were ISO 14001 certified, because automobile manufacturers demand this certification in order to work with any company. However, it was also observed in the case study that many of the certification benefits were not properly understood. Once the companies became certified, some environmental principles cease to be prioritized by the companies, and therefore the positive effects of these principles diminish. This attitude demonstrates that some companies do not truly believe in the real advantages of certification and, therefore, they lose certain potential benefits. Gadenne et al. (2009) observed several companies with "green appearances," but they implemented environmental practices poorly.

Another objective of this research was to confirm that environmental proactivity could provide benefits to companies in the Valencian Community industrial network. Eco-efficiency strategies can be recommended for virtually any business type, and lessening environmental impact by saving energy or reducing waste is often rewarded with cost savings. Many types of companies can reap benefits from adopting an environmentally proactive attitude, even companies that supply other companies, such as the automotive supply industry, those that generate waste, such as the food industry, or those that require high levels of energy consumption, such as the tile industry (Gabaldon, 2003). An eco-efficiency strategy is recommended for the Valencian industrial network, because it encourages companies to increase productivity by reducing environmental impact and its associated costs. This research can enable companies' management teams to acquire information on how to prioritize environmental investments. The benefits of ISO 14001 are widely recognized, and ISO 14001 certification is recommended whenever possible. Nevertheless, if certification is not possible, as is the case for many SMEs with limited resources, this should not be a reason to forget that environmental proactivity can be a source of competitive advantages. Simple systems can be adopted in order to improve energy use and minimize waste, and such systems would have direct, positive impacts on companies' productivity. 
In conclusion, the benefits of institutional environmental proactivity should be suggested to industrial policy makers. Environmental proactivity improves companies' productivity, improves companies' corporate image, and can lead to business opportunities to fulfill the needs of new niche markets. Future lines of research could move towards larger quantitative studies, include other sectors or other regions, or compare and contrast analogous industrial sectors in different regions in order to analyze the effects of different environmental legislation.

\section{ACKNOWLEDGMENTS}

The authors would like to thank the Spanish Economy and Competitiveness Ministry for its support through the research project (EC02011-27369), and the Universitat Politècnica de València for its research funding to the project (PAID-06-2011-1879). Also the Master GEPS for its valuable support and the Microcluster "Globalization, tertiarisation, tourism and heritage: towards a sustainable management of the past and future".

\section{AUTHOR INFORMATION}

Conrado Carrascosa-López: Degree in Industrial Engineering by the Universidad Politécnica de Valencia. Assistant Professor in industrial competitiveness and economics, at the School of Industrial Engineering at the Universidad Politécnica, Valencia, Spain. Research Interest: Environmental proactivity, E-mail: concarlo@upvnet.upv.es

Maria-del-Val Segarra-Oña: $\mathrm{PhD}$ in Management and Degree in Industrial Engineering. Associate Professor in Innovation, Competitiveness, Regional Development and Industrial Policies at the School of Industrial Engineering at the Universidad Politécnica, Valencia (Spain). Research Interest: Environmental proactivity, eco-innovation and economic performance applied to industrial and service sectors. E-mail: maseo@omp.upv.es. Corresponding author.

Angel Peiró-Signes: $\mathrm{PhD}$ in Business Administration and Degree in Industrial Engineering. Assistant Professor in Analytical Accounting in Manufacturing firms and Strategic Management at the Faculty of Business Administration at the Universidad Politécnica de Valencia (Spain). Research Interest: Eco-innovation and economic performance of companies, applied to industrial and service sectors. E-mail: anpeisig@omp.upv.es.

Baldomero Segura-García-del-Rio: PhD Agronomist by the Universidad Politécnica de Valencia. Professor in Economics at the Agronomic Engineering in Universidad Politecnica, Valencia, Spain. Research interest: International economy, Risk analysis, Financial markets, RSC and the environment, E-mail: bsegura@upvnet.upv.es

\section{REFERENCES}

1. Aragón-Correa JA, (1998) Strategic proactivity and firm approach to the natural environment. Academy of Management Journal 41(5): 556-567

2. Aragón-Correa JA, Sharma S, (2003) A Contingent Resource-based view of proactive corporate environmental strategy. Academy of Management Review, Vol 28. No. I. 71-88.

3. Aragón-Correa JA, Hurtado-Torres N, Sharma S, García-Morales V. (2008), Environmental strategy and performance in small firms: A resource-based perspective, Journal of Environmental Management, 86, 1, 88-103.

4. Butler, J. (2008) The Compelling "Hard Case" for "Green” Hotel Development, Cornell Hospitality Quarterly, 49 (3), pp. 234-244.

5. Buysse K, Verbeke A, (2003) Proactive environmental strategies: A stakeholder management perspective. Strategic Management Journal, 24, 453-470

6. Clarkson PM, Li Y, Richardson GD, Vasvari FP, (2011):'Does it really pay to be green? Determinants and consequences of proactive environmental strategies. J. Account Public Policy 30, 122-144

7. Darnall N, Henriques I, Sadorsky P, (2008) Do environmental management systems improve business performance in an international setting? Journal of International Management 14, 364-376 
8. Darnall N, Henriques I, Sadorsky P, (2010) Adopting proactive Environmental Strategy: The influence of Stakeholders and Firm size. Journal of Management Studies 47: September 2010

9. Delmas M, Hoffmann VH, Kuss M (2011) Under the tip of the Iceberg: Absorptive Capacity, Environmental Strategy, and competitive Advantages Business and Society 50(I) 116-154

10. Fairchild R, (2008) The Manufacturing Sector's Environmental Motives: A Game-theoretic Analysis. Journal of Business Ethics, Vol. 79, No 3, pp. 333-334.

11. Gabaldon, S. Lopez, J. B. Carda, J. B. Legislación y gestiónmedioambiental en la producción de baldosascerámicas, Bol. Soc. Esp. Ceram. Vidr., 42 (3): 169-179, (2003).

12. Gadenne DL, Kennedy J, Mckeiver C, (2009) An empirical Study of environmental Awareness and Practices in SMEs. Journal of Business Ethics 84, 45-63

13. González-Benito J., González-Benito O. (2005), Environmental proactivity and business performance: an empirical analysis, Omega International. Journal of Management Science, 33, 1, 1-15.

14. González-Benito J, González-Benito O, (2006), A Review of Determinant factors of Environmental Proactivity. Business Strategy and the Environment 15, 87-102 (2006)

15. González-Benito J, González-Benito O, (2010) A Study of Determinant Factors of Stake Environmental pressure perceived by industrial companies. Business Strategy and the Environment 19, 164-181

16. Haddock-Fraser JE, Tourelle M, (2010) Corporate Motivations for Environmental Sustainable Development: Exploring the role of consumers in stakeholder engagement. Business Strategy and the Environment 19, 527-542

17. IVEX, InstitutoValenciano de exportación, 2011.Información sectorial. http://www.ivex.es/dms/estudios/informacion_sectorial_CV/ceramico-feb/CERAMICOCV2011.pdf

18. King A.A, Lenox MJ (2001) Does It Really Pay to Be Green? An Empirical Study of Firm Environmental and Financial Performance Journal of Industrial Ecology Volume 5, Number 1 105-116

19. Martín-Tapia I, Aragón-Correa J, Rueda-Manzanares A, (2010) Environmental Strategy and exports in medium, small and micro-enterprises. Journal of World Business 45, 266-275

20. Melnyk S, Sroufe R, Calantone R, (2003) Assessing the impact of environmental management systems on corporate and environmental performance Journal of Operations Management 21 (2003) 329-351

21. Murillo-Luna J, Garcés-Ayerbe C, Rivera-Torres P, (2008) Why do patterns of environmental response differ? A stakeholders' pressure approach. Strategic Management Journal 29: 1225-1240

22. Porter M, Van der Linde C, (1995) Toward a New Conception of the Environment-Competitiveness Relationship Journal of Economic Perspectives Vol. 9 No 4 pp. 97-118

23. Rivas J, Magadán M (2010) Less green taxes and more control over pollutant industries: a theoretical proposal Environmental Engineering and Management Journal, 9 (9) 1173-1177

24. Rondinelli D, Vastag G (2000) Panacea, common sense or just a label? The value of ISO 14001 Environmental management systems. European Management Journal Vol. 18, No. 5, pp. 499-510, 2000

25. Segarra-Oña M, Carrascosa-López C, Segura-García-del-Río B, Peiró-Signes A (2011) Empirical analysis of the integration of environmental proactivity into managerial strategy. Identification of benefits, difficulties and facilitators at the Spanish automotive industry, Environmental Engineering and Management Journal, 10 (12): 1821-1830.

26. Vargas-Vargas M, Meseguer-Santamaría ML, Mondéjar-Jiménez J, Mondéjar-Jiménez JA, (2010) Environmental Protection Expenditure for Companies: A Spanish Regional Analysis, International Journal of Environmental Research, 4 (3) 373-378.

27. Villavicencio, J. M. (2007) Factores que inciden en el desempeño exportador de lasPymes: una aplicación empírica, Tec Empresarial, 1(4) 28-40. 
NOTES 